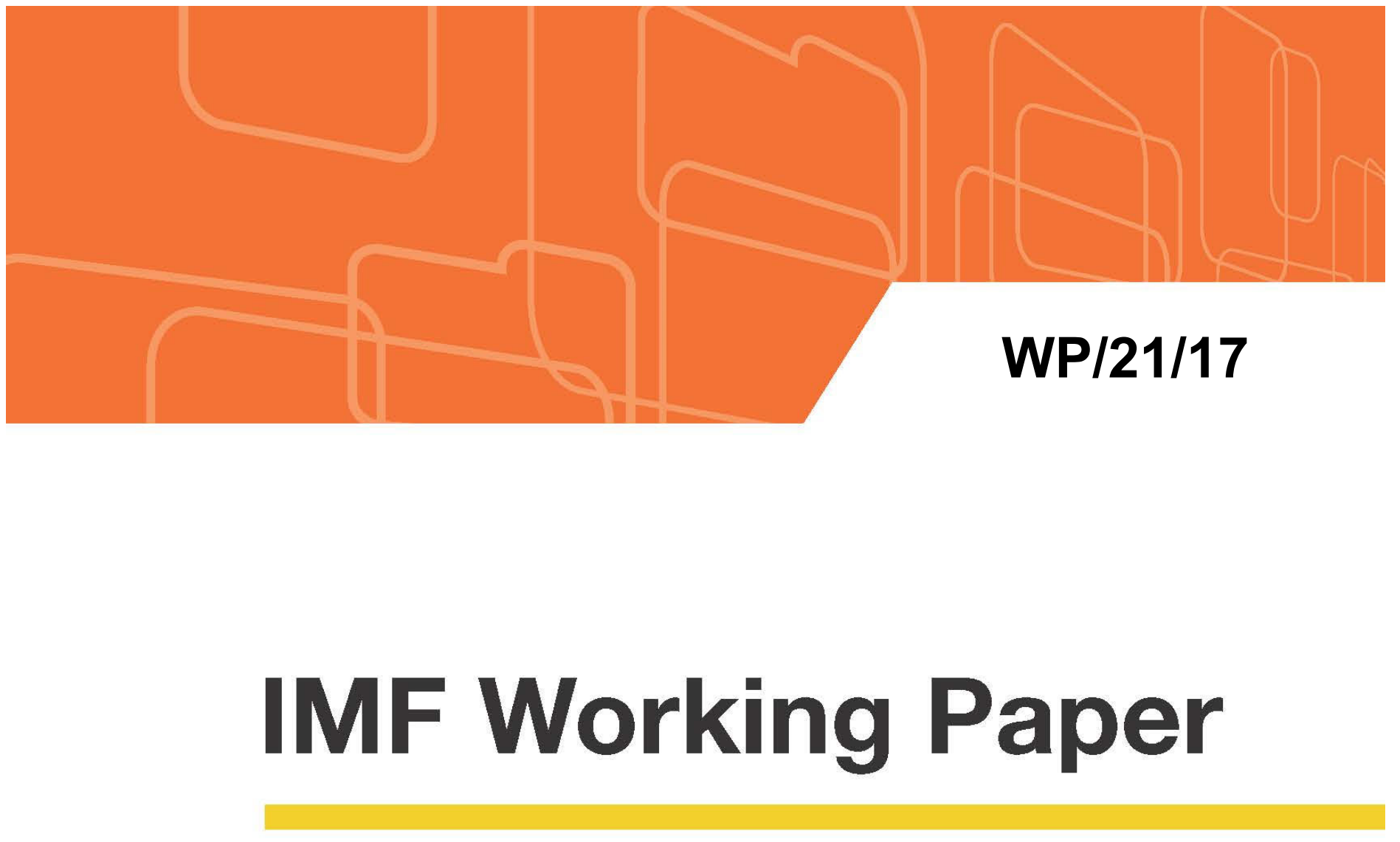

\title{
Fiscal Dominance in Sub-Saharan Africa Revisited
}

by John Hooley, Lam Nguyen, Mika Saito, and Shirin Nikaein Towfighian

IMF Working Papers describe research in progress by the author(s) and are published to elicit comments and to encourage debate. The views expressed in IMF Working Papers are those of the author(s) and do not necessarily represent the views of the IMF, its Executive Board, or IMF management.

$$
\text { I N T E R N A T I O N A L M O N E T A R Y F U N D }
$$




\title{
IMF Working Paper
}

\author{
African Department
}

Fiscal Dominance in Sub-Saharan Africa Revisited

Prepared by by John Hooley, Lam Nguyen, Mika Saito, and Shirin Nikaein Towfighian

Authorized for distribution by Céline Allard

January 2021

IMF Working Papers describe research in progress by the author(s) and are published to elicit comments and to encourage debate. The views expressed in IMF Working Papers are those of the author(s) and do not necessarily represent the views of the IMF, its Executive Board, or IMF management.

\begin{abstract}
This paper explores the causes and consequences of fiscal dominance over monetary policy in Sub-Saharan Africa (SSA). Fiscal dominance has always been a pressing problem as it can contribute to inflation and macroeconomic instability, and increasingly so as fiscal deficits and public debt are rising in many SSA countries. We find that legal limits and availability of alternative financing options play an important role in determining the extent to which government deficits tend to be financed by the central bank. We also find economically significant effects of central bank lending to government on the exchange rate and inflation.

JEL Classification Numbers: E31, E52, E58, E61, E62, F31, H62, H63

Keywords: Inflation, monetary policy, central bank, fiscal policy, fiscal dominance, policy coordination, exchange rate, fiscal deficit, sovereign debt

Author's E-Mail Address: jhooley@imf.org; 1hn022@ucsd.edu; msaito@,imf.org; and snikaeintowfighian@,imf.org.
\end{abstract}




\section{InTRODUCTION AND MAIN FIndingS}

This paper takes a fresh look at fiscal dominance in Sub-Saharan Africa (SSA) against the backdrop of rising debt and additional budgetary pressures from the Covid-19 pandemic. 'Fiscal dominance', or central bank lending to government for fiscal purposes (beyond any legal limit), has long been a feature of policy discussions in SSA. But questions of whether (or by how much) central banks should finance fiscal deficits have recently returned to the forefront of the policy debate in the wake of increased borrowing needs from the steady rise in government deficits since the mid-2000s and additional budgetary pressures from the 2020 Covid-19 pandemic (IMF 2018 and IMF 2020). ${ }^{1}$ This paper therefore examines evidence for central bank financing of government deficits and debt and its macroeconomic impact in SSA in the two decades prior to the onset of the current crisis.

Central bank lending to governments has a long history and has been associated with hyperinflationary episodes in SSA and elsewhere. In fact, the first central banks were created explicitly to meet fiscal needs (Riksbank created in 1668 and the Bank of England created in 1694). Many central banks founded in the nineteenth century were also fiscally motivated, often for financing wars (Bordo \& Siklos, 2018). At the same time, many hyperinflation episodes have been associated with central bank financing of government debt: Weimar Germany (1922-23), Hungary (1945-46), Greece (1941-45), Latin America during the debt crisis in the 1980s, to name a few (Hanke \& Krus, 2012). ${ }^{2}$ Governments that borrow from their central banks to finance fiscal deficits or debt has long been a pressing problem in many countries in the SSA region too. The episodes in Zaire (1991-92 and 199394), Angola (1994-97), Democratic Republic of Congo (1998) and Zimbabwe (2007-08, 2019-20) are the starkest examples where unsustainable deficit financing by the central bank led to hyperinflation.

As a result of the macroeconomic risks from fiscal dominance, legal limits on central bank financing of fiscal debt became a feature of Central Bank Acts in all regions over the past three decades. In most countries, advances and loans cannot exceed 10 percent of government revenues of the previous fiscal year or an average of the last three fiscal years (Jácome and others, 2012). The aim of allowing some limited budgetary financing from the central bank is to provide a lender-of last-resort facility to cover intra-year fluctuations in revenue in economies where alternative market financing options may be sparse and shocks relatively frequent (Cottarelli, 1993). In SSA countries, these limits are set somewhat higher compared to other regions, but still permit only modest and temporary levels of central bank lending to government.

\footnotetext{
${ }^{1}$ For example, in the context of the Covid-19 pandemic, the South African Reserve Bank faced political pressure to directly fund government, while the Bank of Ghana was quick to extend additional financing to the government (See Cotterill, 2020 and Ministry of Finance of Ghana, 2020).

2 Phillip Cagan (1956) defined hyperinflation as beginning when monthly inflation rates exceed 50 percent and ending in the month before the rate declines below 50 percent (where it must remain for at least a year).
} 
In practice, however, lending by central banks to government in SSA has not been modest and temporary as intended in the law. Central bank lending to government during 2001-17 amounted to 2 percent of GDP on average for SSA countries, compared to less than $1 / 2$ percent in other regions, and in four SSA countries, this ratio exceeded 10 percent of GDP. ${ }^{3}$ Furthermore, after declining in the first part of the past decade, it started to pick up again since 2014, coinciding with a rise in deficits and debt. Unsurprisingly, large increases in central bank lending to government meant that legal limits were often exceeded: our study suggests by 16 percent of revenue on average.

Yet despite the importance of central bank lending in practice, the academic literature has given limited attention to fiscal dominance, either in SSA or elsewhere. The gap in the literature likely reflects the declining importance of central bank financing of government deficits in advanced economies over the past few decades. ${ }^{4}$ However, there is a closely related strand of literature that looked at the much broader concept of central bank independence and inflation. For example, based on a sample of 16 advanced economies between 1955 and 1988, Alesina and Summers (1993) found a negative relationship between central bank independence and both the level and the variance of inflation. Fischer (1995) presented theoretical and empirical evidence to support the case for enhancing central bank independence. Most recently, Garriga and Rodriguez (2020) found that higher central bank independence is associated with lower inflation rates, using a sample of 118 developing countries between 1980 and 2013. These studies tended to focus on monetary policy aspects only and used broad composite indices of de jure independence, in which central bank lending was only one element. A few studies that touch on fiscal aspects have not found a strong relationship between central bank independence and fiscal policy, including Sikken and de Haan (1998) who investigated its relationship with budget deficits, and Alpanda and Honig (2009) who examined its role during political monetary cycles. There are a few individual country case studies of central bank lending on inflation in emerging and lowincome economies (Brazil, Ghana, DRC), but there has been no systematic empirical study.

This paper therefore represents a first attempt to examine fiscal dominance in SSA. It attempts to answer three main questions: First, what is the evidence for central bank lending to government in practice and how does it relate to legal limits? We construct a new database of quantitative legal limits and compare these with the actual level of lending. Second, why do governments choose to finance deficits through central bank borrowing? We empirically estimate the impact of factors such as availability of outside financing options and whether legal limits are binding in practice. Third, should we care? We attempt to identify the macroeconomic impacts of fiscal dominance on monetary aggregates, the exchange rate, and inflation.

\footnotetext{
${ }^{3}$ The median for SSA countries is 2 percent of GDP, while the arithmetic mean is 4 percent during the same time period. Given the presence of extreme outliers in the sample, the median is reported in this paper.

${ }^{4}$ The ongoing Covid-19 crisis notwithstanding, during which some advanced economies have provided loans directly to government. For example, the Bank of England temporarily increased the limit on its overdraft facility with the Treasury: https://www.bankofengland.co.uk/news/2020/april/hmt-and-boe-announcetemporary-extension-to-ways-and-means-facility.
} 
Our main finding is that although legal limits have been frequently breached, they have posed a constraint, analogous to a 'speed limit.' Our evidence shows that the recourse to the central bank when deficits rise is indeed lower when legal limits are in place. The effect of legal limits is therefore analogous to a speed limit for car drivers; the limit is often exceeded, but rarely by an excessive amount. Our results also show that when more financing options are available, the less central bank financing is used. We also find conditionality that seeks to limit central bank lending under Fund-supported programs does in fact pose a constraint.

Second, central bank deficit financing matters for inflation. We find a statistically significant contemporaneous impact on the exchange rate and a lagged impact on inflation. An increase in central bank credit to the government by one percentage point of GDP - or about five percentage points of revenue-is associated with the depreciation of the exchange rate by one percentage point contemporaneously and an increase in inflation by half a percentage point a year later. These results are also robust to a number of tests, including using alternative variations of the dependent variable, estimation techniques and sets of control variables.

The rest of the paper proceeds as follows. Section II presents stylized facts on fiscal dominance in SSA and introduces the database on legal limits. Section III discusses the empirical approach and results for estimating the determinants of fiscal dominance. Section IV then describes the approach for estimating the macroeconomic impact of shocks to central bank claims. Section V concludes.

\section{Stylized Facts on Fiscal Dominance in SSA}

\section{A. Definitions and Source Data}

\section{Let us define a few key concepts.}

- In this paper, fiscal dominance is referred to as a central bank's lending to the government for fiscal purposes above any legal limits. 5 Separating any central bank's claims on government into monetary and fiscal policy purposes is not straightforward. Some claims are typically extended for monetary policy purposes. For example, central banks may hold treasury bills for liquidity management purposes (or for conducting open market operations). In advanced and some emerging market economies, unconventional monetary policies (UMP) have also involved substantial increases in central bank holdings of government bonds typically when the policy rate has reached the zero-lower bound. On the other hand, claims extended to accommodate fiscal needs are typically through the provision of loans to government through overdraft facilities, although

\footnotetext{
5 There is no agreed definition of fiscal dominance in the literature, though most refer to central bank financing. A definition is provided in IMF (2020), refer to legal limits, emphasizes financing that is separate from the central bank goals/remit: 'direct financing [by the central bank] motivated by the government's desire to reduce, at least temporarily, the cost of its borrowing that directly or indirectly interferes with monetary policy.'
} 
governments may also issue bonds to the central bank for fiscal needs (or convert outstanding overdraft facilities into a long-term bond).

For our sample of SSA central banks, direct government bond issuance to central banks for fiscal purposes or securitization of overdrafts has, to our knowledge, only occurred in a few countries and on an exceptional basis; we therefore assume that central bank holdings of government securities are mostly for monetary policy purposes, while loans and advances to governments are for fiscal policy purposes. We also take comfort from the fact that on average, SSA central banks' securities holdings are smaller than their stock of loans, although in our empirical work we include securities holdings in our measure of central bank financing in our robustness checks. ${ }^{6}$

- Central bank financing (CBF) is therefore measured using the outstanding end-year stock of the central bank's loans and advances to central government from the IMF's International Financial Statistics database, available from 2001-2017.7 Loans, as opposed to total claims, are used for the reasons described above. We also use gross loans, and do not net out government deposits, since legal limits are typically applied on a gross basis and deposits are not under control of the central bank. However, to check the robustness of our results, we also take a difference of the outstanding stock of loans from one year to the next to measure new loans extended each year.

- We construct a database of numerical legal limits on central bank financing from central bank Acts (typically found in the section on relations with the government) in SSA. We source the current and historical Acts from the IMF's central bank legislation database (CBLD), including relevant amendments where available, to construct a time series for each country of effective legal limits. ${ }^{8}$ Table A1 in the Annex presents a summary of the legal limits found in the most recent central bank Act. Out of 45 SSA countries, 41 had legal limits in $2017 .{ }^{9}$

Countries specify legal limits differently (Figure 1). A typical example of how a legal limit is specified in central bank Acts is:

\footnotetext{
${ }^{6}$ Limited central bank holdings of government securities likely reflects, in turn, an absence of UMP needs (the policy rate has not yet reached the lower bound in any SSA country) and the lack of benefit to holding T-bills for liquidity management (since in practice most SSA countries have had a structural surplus of liquidity, which means the central bank needs to sell them to absorb liquidity).

${ }^{7}$ Within-year data on central bank loans are not available. Although there is likely to be some intra-year volatility in central bank lending to government, it is not clear that there would be a particular bias since government financing needs are likely to depend on country-specific seasonality in revenues and expenditures.

${ }^{8}$ The database is publicly accessible on request, at https://cbld.imf.org. Since the latest update of the database was 2016, we complemented the information by checking the Central Bank and Ministry of Finance websites of individual countries for recent legislative updates, up to 2017.

${ }^{9}$ Liberia, South Sudan and Somalia are excluded from our sample of Sub-Saharan African countries due to an incomplete time series of central bank loans to government.
} 
The bank may make temporary advances to the Government in respect of temporary deficiencies in revenue.

The total amount of advances shall not at any time exceed $X$ percent of the revenue of the Government of the previous fiscal year.

As observed in Table A1, the legal limits are typically set in terms of percent of revenue, with varying reference years. The type of lending the limit applies to (e.g., loans, securities, or total claims) varies across countries and in some cases, the limits apply to stock (e.g. of loans outstanding), while in other cases, they apply to flow rather than stock outstanding (e.g., new loans extended each year). Some Acts allow lending in normal times, others only in emergencies. Some allow for securitization of advances, others do not.

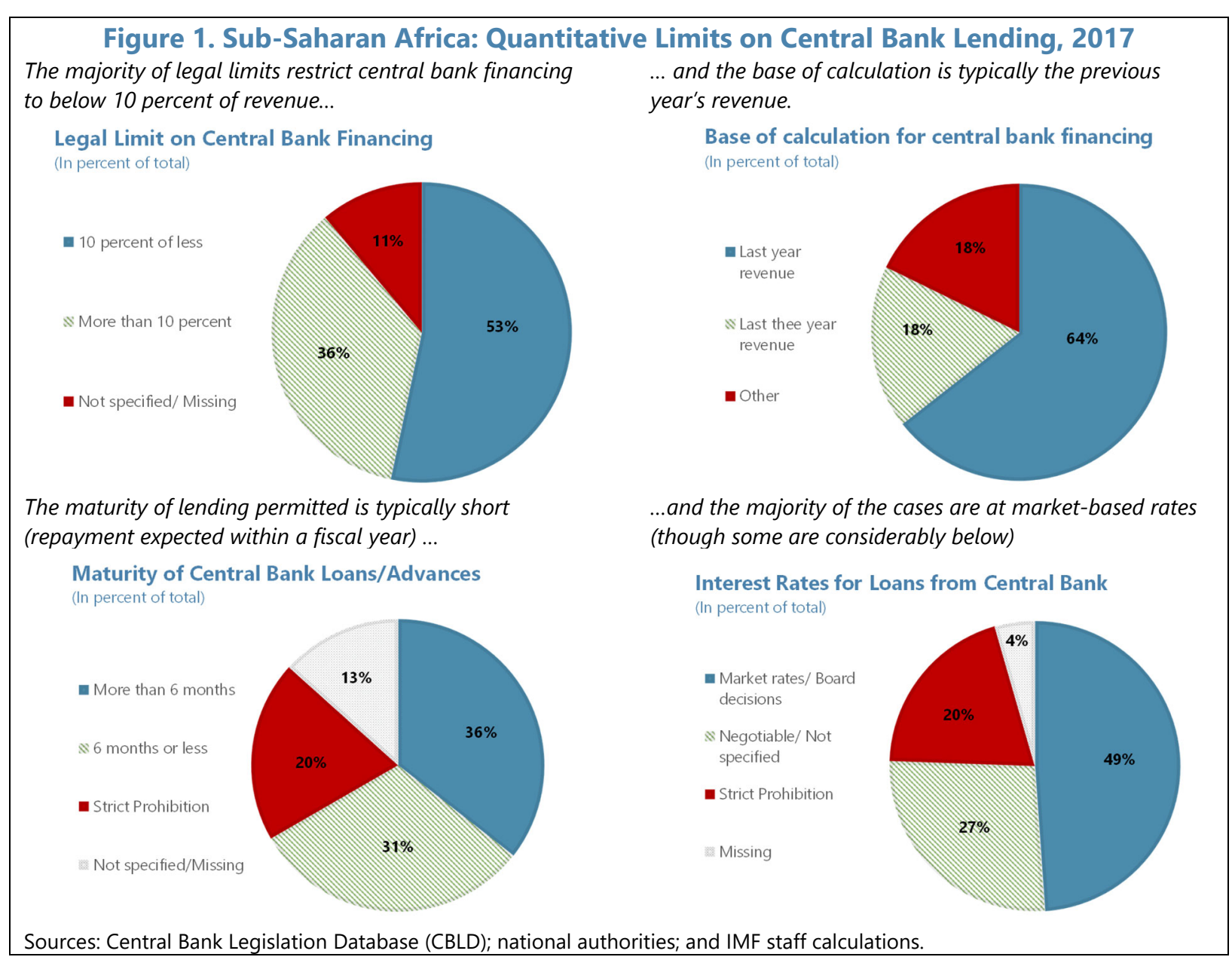

\section{B. Stylized Facts}

Examining central bank claims and legal limits, a first stylized fact is that central bank lending to government is highest in the SSA region. On average, the stock of loans to government was 2 percent of GDP in SSA during 2001-17, compared to 0.2 percent of GDP for the Latin America and Caribbean and the South Asia regions, 0.6 percent of GDP for the 
Middle East and North Africa region and close to 0 percent of GDP for the other regions. ${ }^{10}$ In 2017, the median for SSA countries was 2.2 percent of GDP, and in ten SSA countries, this ratio exceeded 5 percent of GDP (Figure 2).

Second, the two notable increases in central bank loans to government in SSA countries over the past two decades occurred during periods of pressure on public finances. The first increase was during the temporary terms-of-trade shock in 2008-09, although the recourse to central bank financing was contained by drawing on fiscal buffers built up during the preceding commodity price boom (IMF, 2014). The second increase in central bank financing occurred in the wake of the decline commodity prices in mid-2014 which hit SSA countries (particularly commodity dependent countries) hard because they entered the crisis with few buffers and commodity prices remained low for a prolonged period. During the subsequent years, central bank loans to government increased the most in SSA compared to other regions. The timing of the increase also coincided with a rise in gross debt (Figure 2).

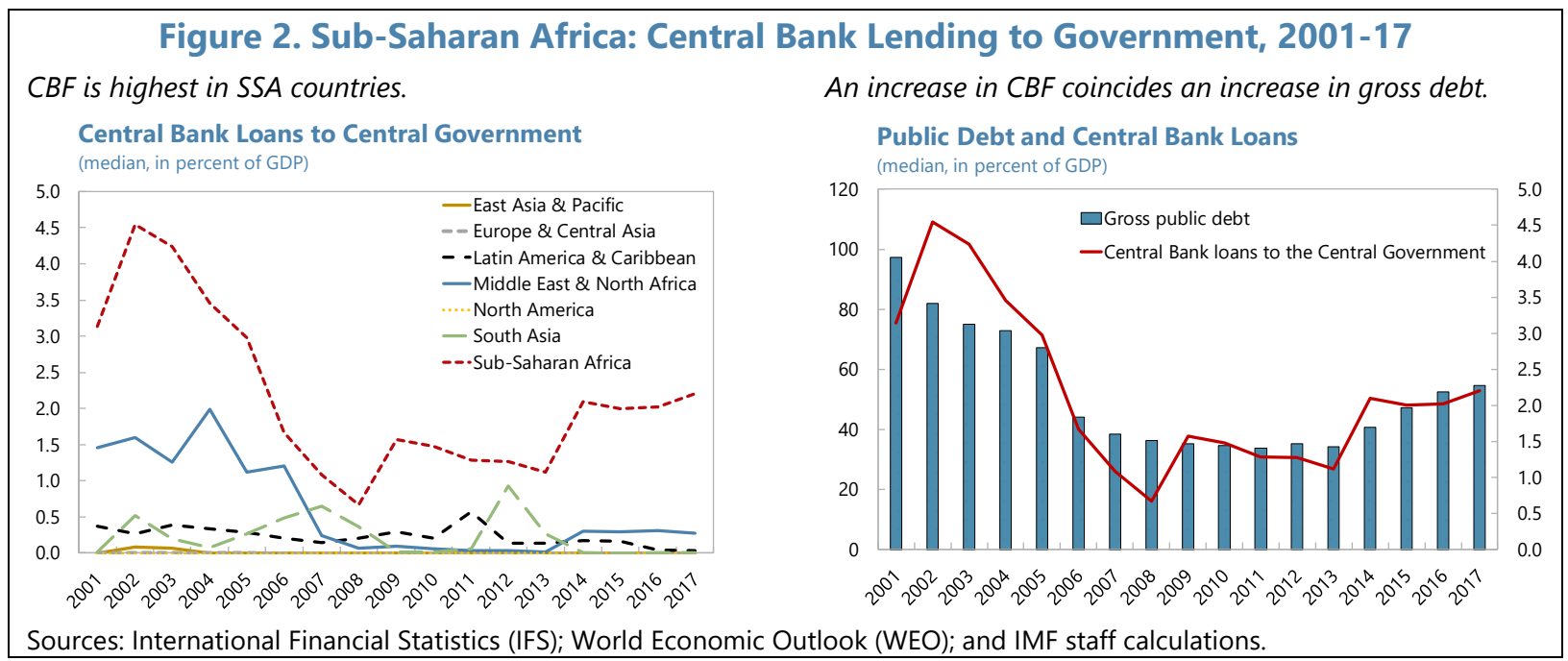

Third, legal limits in SSA countries have become stricter over time. Almost all SSA countries have legal limits on central bank lending (Table A1). These limits, expressed in terms of percent of revenue, vary substantially between 0 and 20 percent of revenue. The median of legal limits was 18 percent in the early 2000s but declined in 2003/4 to 10 percent of revenue, and again in 2017 to 8.5 percent (Figure 3). The mean of legal limits declined more gradually over this period from 15 percent in 2001 to 9.8 percent in 2017.

Fourth, fiscal dominance has declined over time, despite the tightening of legal limits. Central bank lending above the legal limit (what we call "fiscal dominance") appears to be a

\footnotetext{
${ }^{10}$ The difference with respect to other regions is even more pronounced in revenue terms: central bank lending to government during 2001-17 amounted to 12 percent of revenue on average for SSA countries, compared to less than 1 percent in other regions.
} 
systemic phenomenon in SSA. ${ }^{11}$ In 2017 , lending exceeded the limit in between 9 and 29 countries (out of 41 countries) depending on whether the legal limit is interpreted to apply to the outstanding stock or the flow of lending (Figure 4). ${ }^{12}$ Noncompliance (or the incidence of fiscal dominance) is more common for those with stricter limits (i.e., legal limits are interpreted as applied to stock of loans outstanding), most likely because some central banks are carrying legacy loans from the past. Nevertheless, the amount by which central bank lending exceeds legal limits (or the magnitude of fiscal dominance) has fallen, despite the tightening in limits.

\section{Figure 4. Sub-Saharan Africa: Fiscal Dominance, 2001-17}

The incidence of fiscal dominance is systemic, but...

Incidence of Fiscal Dominance (number of countries exceeding the legal limit)

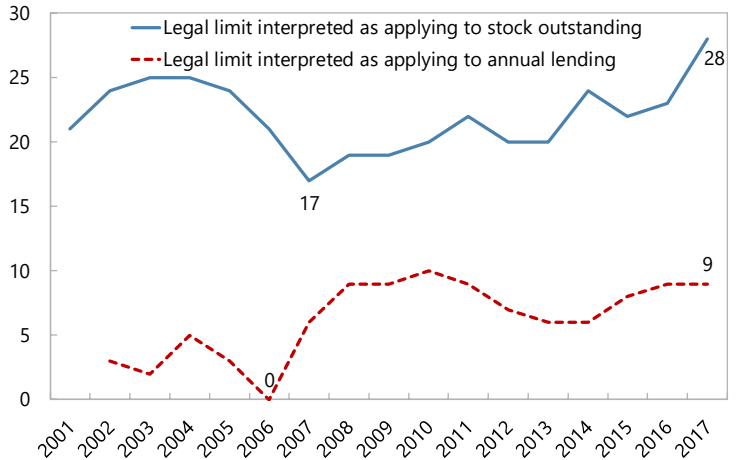

Figure 3. Sub-Saharan Africa: Legal Limits, 2001-17

(in percent of revenue)

Legal limits have become stricter over time.

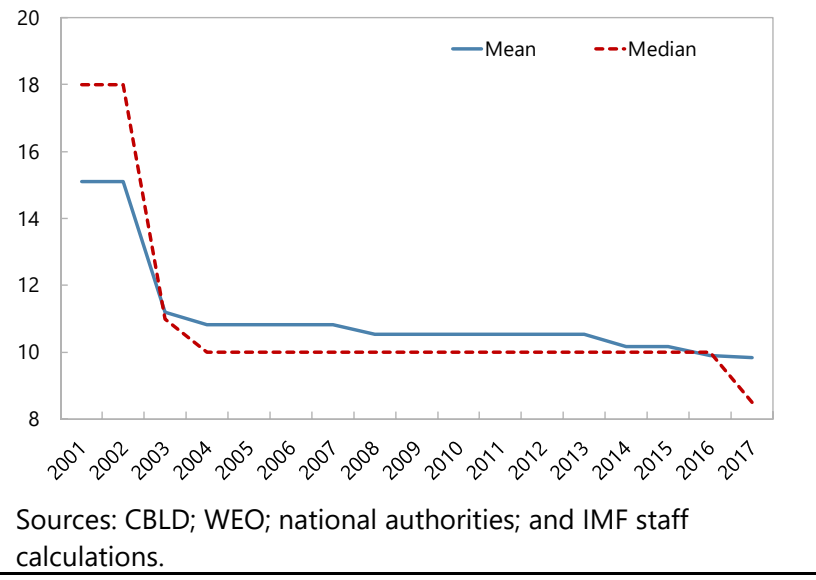

Sources: CBLD; national authorities; MFS; WEO; and IMF staff calculations.

\footnotetext{
${ }^{11}$ However, we cannot assess whether a legal violation occurred in practice. There may be many reasons why it doesn't, including differences in legal interpretations, accounting practices, and independence of the judiciary.

${ }^{12}$ There is sometimes ambiguity in the central bank Act whether the limit applies to the outstanding stock of loans, or new lending only. When it is specified, the laws always refer to the outstanding stock but when it is not specified there is a possibility the law may be interpreted as applying to new lending, particularly in countries with large legacy central bank claims on government.
} 


\section{Why DO GOVERNMENTS BORROW FROM CENTRAL BANKS?}

\section{In this section, we examine the effects of legal restrictions and alternative financing options on central bank lending. Why do governments borrow from central banks? The} most obvious reason is because the government has a financing need (otherwise no need to borrow from anyone, let alone the central bank). ${ }^{13}$ A more interesting question therefore is what determines the extent to which a government meets its financing need through recourse to the central bank, relative to other sources of funds?

We also examine the effect of other restrictions on central bank lending, such as conditionality in IMF-supported programs. In addition to limits on central bank lending in legislation, quantitative ceilings on central bank lending to government are often observed in IMFsupported macroeconomic adjustment programs in the region (Figure 5). The conditionality to amend (revise downwards) the limits in the laws themselves also features

Figure 5. Sub-Saharan Africa: Conditions in IMF-Supported Programs, 2002-17

(number of countries)

Limits on central bank lending feature often in IMFsupported programs.

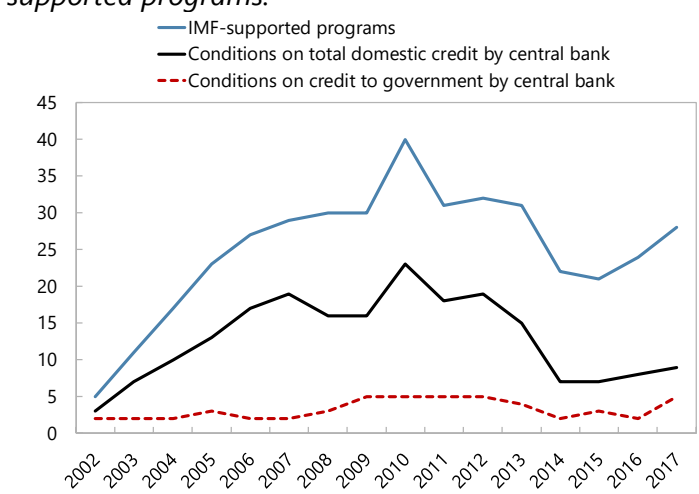

Sources: MONA database; and IMF staff calculations. Note: Programs that started before 2002 are not included. in IMF-supported programs.

\section{A. Empirical approach}

Governments typically have several financing options other than borrowing from the central bank. A government typically finances its fiscal deficits by a combination of borrowing abroad, borrowing from domestic banks (either from commercial banks or the central bank), and borrowing from domestic nonbank institutions (e.g., pension funds). ${ }^{14}$ The amount of borrowing from the central bank therefore depends on the size of financing needs and the government's ability to borrow from the market (e.g., by selling sovereign bonds to commercial banks, pension funds, or nonresidents). ${ }^{15}$ The availability of external assistance (concessional loans from official bilateral or multilateral creditors), the size of the

\footnotetext{
13 This is of course a bit of a simplification: several governments continue to issue marketable debt, but for market development purposes even when they have a fiscal surplus, which they might use to retire existing debt or build cash buffers.

${ }^{14}$ Running arrears to suppliers or staff has also sometimes been an informal way of borrowing in many SSA countries but is not considered in this paper, due to data constraints.

15 'Ability' of the government to borrow from the market here can refer to both the existence of an investor base for additional debt issuance but also also willingness to pay the market rate, since where notional borrowing rates are high, the central bank may not be the only option, just the apparently (much) cheaper option.
} 
government's deposits, and the extent of legal or any other limits on central bank financing also affect the government's borrowing from the central bank.

In this context, we estimate the following empirical model. The model is estimated on annual data with central bank lending to government in country $i$ at time $t$ as the dependent variable.

$Y_{i t}=\beta_{1} F_{i t}+\beta_{2} F_{i t} \cdot L_{i t}+\beta_{3} F_{i t} \cdot M K T_{i t}+\beta_{4} F_{i t} \cdot Q P C_{i t}+[\mathbf{a}]^{\prime} \mathbf{X}_{i, t}+[\mathbf{b}]^{\prime} \mathbf{Z}_{i, t-1}+\varsigma_{i}+\theta_{t}+\varepsilon_{i t}$

where

$Y_{i t}$ : central bank lending (loans and advances outstanding) as a percent of GDP;

$F_{i t}$ : fiscal deficit as a percent of GDP;

$L_{i t}$ : legal limits on central bank lending as a percent of revenue;

$M K T_{i t}$ : dummy for market access ( $=1$ if country issues government securities

over 1 year maturity, 0 otherwise);

$Q P C_{i t}$ : dummy for IMF conditionality on central bank lending ( $=1$ if country

has conditions in IMF-supported program, 0 otherwise);

$\mathbf{X}_{i, t}:$ a vector of $\left[L_{i t}, M K T_{i t}, Q P C_{i t}\right]$;

$\mathbf{Z}_{i, t-1}:$ a vector of control variables;

$\varsigma_{i}:$ country fixed effect;

$\theta_{t}:$ time fixed effect; and

$\varepsilon_{i t}:$ residual.

This specification has one particularly noteworthy feature. The interaction terms allow us to assess how legal limits, domestic market development, and IMF conditionality affect the amount fiscal deficits are financed by the central bank. For example, we can estimate how much of a unit increase in fiscal deficit will be financed by central bank lending by looking at the partial derivative of equation (1) with respect to $F_{i t}$ :

$\frac{\partial Y_{i t}}{\partial F_{i t}}=\beta_{1}+\beta_{2} L_{i t}+\beta_{3} M K T_{i t}+\beta_{4} Q P C_{i t}$,

We expect a positive sign for $\beta_{2}$ and negative signs for $\beta_{3}$ and $\beta_{4}$, as lower legal limits, more domestic market development, and IMF conditionality should imply lower central bank lending, respectively.

We include several other lagged control variables and estimate the model using the Arellano-Bond estimator. The lag of the dependent variable is included as a regressor to account for inertia. A few other lagged variables (lags of real GDP growth, lag of government deposit to GDP ratio, and lag of government debt to GDP ratio) are included to 
control for country-specific variation in the macroeconomic environment, not captured by the country- and time-fixed effects. We estimate the dynamic panel model using the ArellanoBond Generalized Method of Moments (GMM) technique since our panel is large in the cross-sectional dimension relative to the time dimension. ${ }^{16}$

\section{B. Results}

Our database covers 41 countries and a period of 18 years, over 2001-2017. ${ }^{17}$ Descriptive statistics of key variables are presented in Table 1. For all our variables of interest, a full time series of data is available for most of the countries in our sample.

Table 1. Sub-Saharan Africa: Descriptive Statistics, 2001-17

(in percent; otherwise indicated)

\begin{tabular}{lccccc}
\hline Variable & $\begin{array}{l}\text { Number of } \\
\text { observations }\end{array}$ & Mean & $\begin{array}{l}\text { Standard } \\
\text { Deviation }\end{array}$ & Minimum & Maximum \\
\hline Central bank claims/GDP & 719 & 6.1 & 8.9 & 0.0 & 63.2 \\
\hline $\begin{array}{l}\text { Percentage change of central bank } \\
\text { claims/GDP }\end{array}$ & 675 & 5.2 & 22.8 & -217.5 & 150.7 \\
\hline Central bank loans/GDP & 719 & 3.7 & 5.6 & 0.0 & 61.5 \\
\hline $\begin{array}{l}\text { Percentage change of central bank } \\
\text { loans/GDP }\end{array}$ & 677 & 2.1 & 21.6 & -260.5 & 162.1 \\
\hline Fiscal deficits/GDP & 756 & 2.6 & 5.6 & -27.2 & 30.4 \\
\hline Real GDP Growth & 764 & 4.6 & 5.2 & -36.7 & 60.1 \\
\hline Legal Limit/revenue & 726 & 11.0 & 7.9 & 0.0 & 25.0 \\
\hline Government deposits/GDP & 731 & 4.4 & 5.1 & 0.0 & 33.0 \\
\hline $\begin{array}{l}\text { Government gross debt/GDP } \\
\text { Dummy for domestic market }\end{array}$ & 754 & 62.1 & 49.6 & 0.5 & 406.7 \\
\hline $\begin{array}{l}\text { development } \\
\text { (1 or 0) }\end{array}$ & 764 & 0.5 & 0.5 & 0.0 & 1.0 \\
\hline $\begin{array}{l}\text { Dummy for IMF conditionality on } \\
\text { central bank lending (1 or 0) }\end{array}$ & 809 & 0.2 & 0.4 & 0.0 & 1.0 \\
\hline
\end{tabular}

Sources: WEO; IFS; and IMF staff calculations.

Our baseline results confirm both the existence of fiscal dominance in SSA and its mitigation by de jure limits and outside financing options. Our main findings are based on estimating variants of equation (1) and are presented in Table 2 and summarized below:

- The size of central bank lending does depend on financing needs. The size of fiscal deficits and the size of central bank lending are highly correlated.

\footnotetext{
${ }^{16}$ See Arellano and Bover (1995) and Blundell and Bond (1998).

${ }^{17}$ Countries were excluded in cases where i) no Central Bank Act was found (Burundi and Eritrea) and, ii) where the Central Bank Act did not specify a numerical legal limit on central bank lending (South Africa and Seychelles).
} 
- The presence of limits on central bank lending matters. Limits on central bank lending, both in the form of legislation and IMF conditionality, do not seem to have a strong association with the size of central bank lending itself (the coefficients on legal limits and IMF conditionality are not statistically significant in Models 2-5). However, having limits on central bank lending does matter. That is, the government's propensity to borrow from the central bank is higher if limits are looser (the coefficients on interaction terms are all statistically significant in Models 2-5).

- The government's ability to borrow from the market does limit central bank financing. Being able to raise resources from the market, by issuing sovereign bonds to banks, nonbanks, and nonresidents, tends to be associated with lower central bank lending (coefficients on the dummy for market development in Models 3 and 5 are statistically significant). Being able to raise resources from the market also matters (coefficients on interaction terms are all statistically significant in Models 3 and 5).

The size of coefficients is economically meaningful. Using the results of Model 5, equation (2) can be expressed as follows:

$$
\frac{\partial Y_{i t}}{\partial F_{i t}}=0.027+0.006 L_{i t}-0.062 M K T_{i t}-0.026 Q P C_{i t},
$$

This result has three implications on the government's propensity to resort to central bank financing at margin.

- On average, legal limits (mean) are about 11 percent, $L_{i t}=11$. This implies that on average, about 9 percent of the fiscal deficit is financed by the central bank.

$$
\frac{\partial Y_{i t}}{\partial F_{i t}}=\left(0.027+0.006 L_{i t}\right) \approx 0.09
$$

- If the government has alternative options to borrow $\left(M K T_{i t}=1\right)$, then only about 3 percent of the fiscal deficit is covered by central bank financing (similar results to Model $3)$.

$$
\frac{\partial Y_{i t}}{\partial F_{i t}}=\left(0.027+0.006 L_{i t}-0.062 M K T_{i t}\right) \approx 0.03
$$

- In addition, if the government has a Fund-supported program with a condition on domestic borrowing or central bank borrowing $\left(Q P C_{i t}=1\right)$, then almost none of the deficit is covered by central bank financing.

$$
\frac{\partial Y_{i t}}{\partial F_{i t}}=\left(0.027+0.006 L_{i t}-0.062 M K T_{i t}-0.026 Q P C_{i t}\right) \approx 0.005
$$


Table 2. Sub-Saharan Africa: Determinants of Central Bank Lending, 2001-17

\begin{tabular}{|c|c|c|c|c|c|}
\hline $\begin{array}{l}\text { Dependent variable: Central bank } \\
\text { loans/GDP }\end{array}$ & $\begin{array}{c}\text { (1) } \\
\text { Model } 1\end{array}$ & $\begin{array}{c}\text { (2) } \\
\text { Model } 2\end{array}$ & $\begin{array}{c}\text { (3) } \\
\text { Model } 3\end{array}$ & $\begin{array}{c}\text { (4) } \\
\text { Model } 4\end{array}$ & $\begin{array}{c}\text { (5) } \\
\text { Model } 5\end{array}$ \\
\hline Fiscal deficits & $\begin{array}{l}0.104^{* * *} \\
(0.0359)\end{array}$ & $\begin{array}{c}0.0362 \\
(0.0254)\end{array}$ & $\begin{array}{l}0.0409 * \\
(0.0209)\end{array}$ & $\begin{array}{c}0.0216 \\
(0.0262)\end{array}$ & $\begin{array}{c}0.0267 \\
(0.0220)\end{array}$ \\
\hline Fiscal deficits* Legal limit & & $\begin{array}{l}0.00458^{* * *} \\
(0.00154)\end{array}$ & $\begin{array}{l}0.00527^{* * *} \\
(0.00142)\end{array}$ & $\begin{array}{l}0.00553^{* * *} \\
(0.00193)\end{array}$ & $\begin{array}{l}0.00622 * * * \\
(0.00175)\end{array}$ \\
\hline $\begin{array}{l}\text { Fiscal deficits*Domestic market } \\
\text { development }\end{array}$ & & & $\begin{array}{l}-0.0639 * * \\
(0.0284)\end{array}$ & & $\begin{array}{l}-0.0622 * * \\
(0.0260)\end{array}$ \\
\hline $\begin{array}{l}\text { Fiscal deficits*IMF } \\
\text { conditionality }\end{array}$ & & & & $\begin{array}{l}-0.0269 * \\
(0.0149)\end{array}$ & $\begin{array}{l}-0.0255^{* *} \\
(0.0123)\end{array}$ \\
\hline Legal limit & & $\begin{array}{l}-0.001 \\
(0.032)\end{array}$ & $\begin{array}{c}0.001 \\
(0.034)\end{array}$ & $\begin{array}{l}-0.004 \\
(0.032)\end{array}$ & $\begin{array}{l}-0.002 \\
(0.034)\end{array}$ \\
\hline Domestic market development & & & $\begin{array}{l}-0.923^{* *} \\
(0.427)\end{array}$ & & $\begin{array}{l}-0.808 * * \\
(0.383)\end{array}$ \\
\hline IMF conditionality & & & & $\begin{array}{l}-0.796 \\
(0.542)\end{array}$ & $\begin{array}{l}-0.689 \\
(0.517)\end{array}$ \\
\hline Lags of central bank loans/GDP & $\begin{array}{l}0.805^{* * *} \\
(0.0461)\end{array}$ & $\begin{array}{l}0.795^{* * *} \\
(0.0381)\end{array}$ & $\begin{array}{l}0.799 * * * \\
(0.0402)\end{array}$ & $\begin{array}{l}0.790 * * * \\
(0.0354)\end{array}$ & $\begin{array}{l}0.795^{* * *} \\
(0.0368)\end{array}$ \\
\hline Lag of real GDP growth & $\begin{array}{l}-0.0163 \\
(0.0115)\end{array}$ & $\begin{array}{l}-0.0223^{* *} \\
(0.0108)\end{array}$ & $\begin{array}{l}-0.0210 * * \\
(0.00980)\end{array}$ & $\begin{array}{l}-0.0221 * * \\
(0.0112)\end{array}$ & $\begin{array}{l}-0.0209 * * \\
(0.0100)\end{array}$ \\
\hline Lag of government deposit/GDP & $\begin{array}{l}-0.0737 \\
(0.0739)\end{array}$ & $\begin{array}{l}-0.0811 \\
(0.0606)\end{array}$ & $\begin{array}{l}-0.0952 \\
(0.0640)\end{array}$ & $\begin{array}{l}-0.0735 \\
(0.0598)\end{array}$ & $\begin{array}{l}-0.0873 \\
(0.0630)\end{array}$ \\
\hline Lag of government debt/GDP & $\begin{array}{c}-0.0100 * \\
(0.00567)\end{array}$ & $\begin{array}{l}-0.00345 \\
(0.00666)\end{array}$ & $\begin{array}{l}-0.00263 \\
(0.00696)\end{array}$ & $\begin{array}{l}-0.00730 \\
(0.00675)\end{array}$ & $\begin{array}{l}-0.00621 \\
(0.00680)\end{array}$ \\
\hline Observations & 667 & 596 & 596 & 596 & 596 \\
\hline Number of countries & 45 & 41 & 41 & 41 & 41 \\
\hline
\end{tabular}

Robust standard errors in parentheses.

*** $p<0.01,{ }^{* *} p<0.05,{ }^{*} p<0.1$

\section{Robustness}

To check the robustness of our results, we estimated several alternative specifications of equation (1). First, to ensure that our results are not influenced by the possible endogeneity of the fiscal deficit, we used lagged values of all independent variables as instruments. Second, to account for the possibility that governments circumvent the legal limit by asking the central bank to lend through channels that are not defined in the legal framework, we 
used total claims on government as the dependent variable rather than total loans. ${ }^{18}$ Third, because some countries may interpret the legal limit differently, we used the flow of lending as the dependent variable. The stock of outstanding loans is used in our baseline model as it corresponds to the definition of the legal limit in central bank Acts. But some countries may interpret the law differently, particularly if there is a large outstanding legacy stock of debt to the central bank. The flow of lending also corresponds more closely to annual financing needs. Finally, we tested whether alternative aspects of outside financing conditions play a role, such as sovereign risk and international capital market access. In all cases, the results from Section III.B remained robust, while the alternative measures of outside financing options did not seem to matter as much as availability of domestic market financing (see Annex I).

\section{What ARE THE MACROECONOMIC IMPACTS?}

In this section, we examine the macroeconomic impact of central bank financing. In particular, we explore its impact on monetary aggregates, inflation and the exchange rate.

We estimate the dynamic response of key macroeconomic variables to a shock by combining the local projections (LP) method of Jordà (2005) with country and time fixed effects. In this paper we use the LP method to estimate the impulse response functions (IRFs), rather than the vector autoregression (VAR) following Sims (1980) since in our panel data setting, the high-dimensionality of a fully-specified VAR would make its estimation prohibitive, whereas with LP it is possible to achieve a reasonable degree-of-freedom in our estimation and even include additional control variables.

Our baseline model is

$W_{i, t+h}=\gamma^{(h)} Y_{i t}+\left[\mathbf{d}^{(h)}\right]^{\prime}$ Controls $+\zeta_{i}^{(h)}+\theta_{t}^{(h)}+u_{i, t+h}$,

where $W_{i, t+h}$ is the macroeconomic variable of interest (base money, inflation, exchange rate, and broad money, Table 3) measured at time horizon $\mathrm{t}+\mathrm{h}, Y_{i t}$ is the ratio of total central bank loans to GDP, and Controls are all the control variables from our baseline regression equation (1). We estimate a separate regression for each horizon $h$. Standard errors are clustered by country and time.

\footnotetext{
${ }^{18}$ One practice sometimes used is securitization of the government's overdraft with the central bank. For example, if the legal limit applies to the overdraft, once the size of the overdraft exceeds the legal limit, the balance may be converted into a bond. In such cases, total claims would be a better measure of fiscal dominance.
} 
Table 3. Sub-Saharan Africa: Descriptive Statistics, 2001-17

(in percent)

\begin{tabular}{lccccc}
\hline Variable & $\begin{array}{c}\text { Number of } \\
\text { observations }\end{array}$ & Mean & $\begin{array}{c}\text { Standard } \\
\text { Deviation }\end{array}$ & Minimum & Maximum \\
\hline Base Money & 729 & 11.0 & 7.4 & 0.1 & 52.8 \\
\hline Exchange rate & 764 & 4.7 & 16.8 & -28.1 & 295.5 \\
\hline Inflation & 764 & 8.2 & 18.0 & -72.7 & 357.3 \\
\hline Broad Money & 764 & 32.4 & 24.2 & 3.1 & 150.8 \\
\hline
\end{tabular}

Sources: WEO; IFS; and IMF staff calculations.

Notes: base money is defined as a ratio to nominal GDP, exchange rates are defined as the annual percent change in terms of national currency per USD, inflation is the annual growth rate of CPI, and broad money is defined as a ratio to nominal GDP.

The results of the IRFs are economically intuitive and some are statistically significant. The precision of the estimations is affected by the large variation in our variables of interest (Table 3). So, while the impact of central bank financing on base money is positive and contemporaneous, no statistical significance is observed. On the other hand, the impact on the exchange rate is contemporaneous and statistically significant. An increase in central bank credit to the government by one percentage point of GDP — or about five percentage points of revenue on average - is associated with a depreciation of the exchange rate by one percentage point contemporaneously. The impact on inflation seems to show with a lag. The same increase in central bank credit to the government is associated with an increase in inflation by half a percentage point a year later. Moreover, the impact on inflation seems to be mostly through the exchange rate channel as the evidence of credit growth (resulting in an increase in aggregate demand) seems absent (Figure 6). 
Figure 6. Sub-Saharan Africa: Impact of Central Bank Financing on Money, the Exchange Rate, and Inflation

The impact of central bank financing on base money is positive and immediate but is not statistically significant...

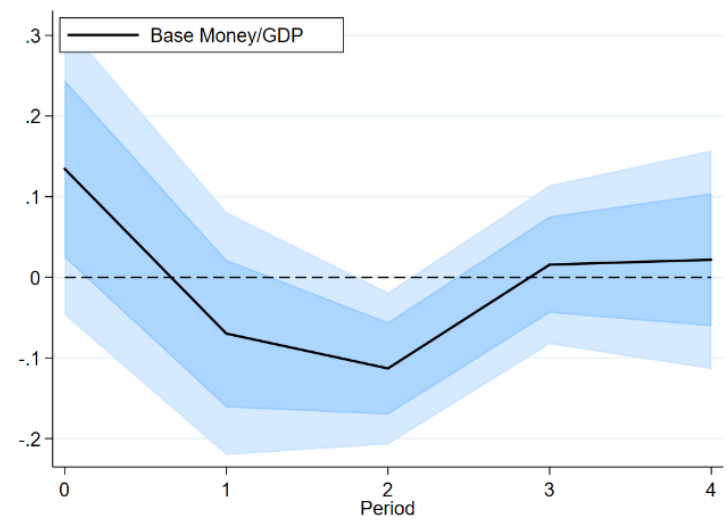
... while the impact on the exchange rate is immediate and statistically significant.

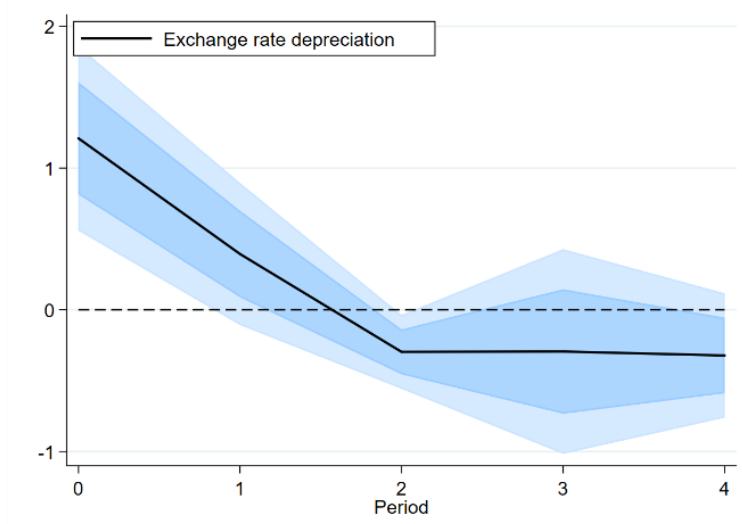

The impact on inflation seems to be through the exchange rate channel and with a lag...

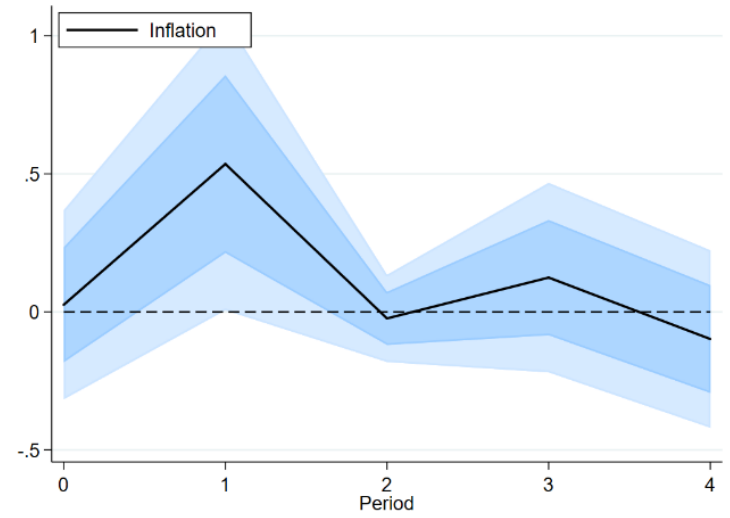

... as the evidence of credit growth (resulting in an increase in aggregate demand) seems absent.

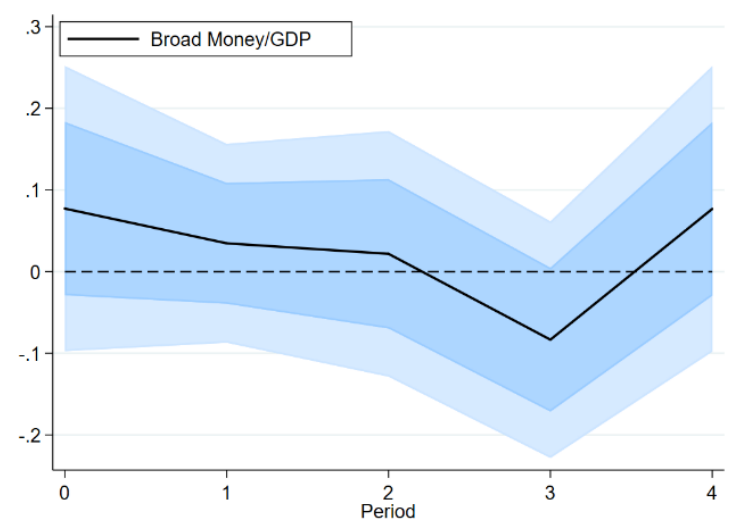

Notes: The Figure shows the impulse response functions for a one unit innovation in the ratio of central bank loans to GDP and presents both the point estimates and the 68 and 90 percent confidence intervals around them.

\section{Concluding Remarks}

Economists and policymakers often warn of the dangers of direct central bank financing of governments, and history provides no shortage of cautionary tales. However, there has been surprisingly little empirical research of the incidence, magnitude or impact of central bank financing of government deficits beyond the most extreme episodes of hyperinflation; instead the focus of studies on the central bank's relations with government has been on the much broader question of central bank independence. This gap in the literature is problematic, since the question of whether (or by how much) to restrict central bank lending to government has been a prominent feature of debates on central bank reform in SSA. And while most central banks in the region do now have legislative limits in place, support has been far from unanimous, while the current Covid-19 crisis has generated some renewed calls to permit direct financing of government. 
Our study therefore represents a first attempt at systematically studying the issue of central bank deficit financing in the SSA region. We show that central bank financing of government deficits has been (1) common, (2) increasing in the past few years, (3) large at around 2 percent of GDP on average, and (4) quantitatively more important relative to other parts of the world. We also construct a new database to document the evolution of de jure limits on central bank financing in SSA. We find that the majority of SSA countries now have formal limits on central bank lending to the governments and that these have become both more numerous and stricter over time. Our new database allows us to define and explore the concept of fiscal dominance: central bank lending to government for fiscal purposes beyond legal limits, this is empirically more relevant given non-zero limits in many countries in the region.

Our empirical findings show that fiscal dominance is both widespread in SSA but efforts to contain it can be effective. Although the incidence of fiscal dominance is high (we observed central bank lending above the legal limit in between 9 and 29 countries in 2017), its magnitude (the amount by which central bank lending exceeds legal limits) has declined over time. In our empirical analysis, we find an important role for policy: countries borrow less from central banks when they have stricter legal limits (or IMF programs that restrict lending) and more developed financial markets. We also find that even low amounts of fiscal dominance can have important macroeconomic effects: central bank lending is associated with exchange rate depreciation and higher inflation subsequently. These findings suggest that fiscal dominance is a relevant macroeconomic issue that policy makers should take seriously in normal times and not just from the perspective of hyperinflation risk. 


\section{REFERENCES}

Alagidede, P. (2016). Central bank deficit financing in a constrained fiscal space. International Growth Center Working Paper.

Alesina, A., \& Summers, L. H. (1993). Central Bank Independence and Macroeconomic Performance: Some Comparative Evidence. Journal of Money, Credit, and Banking, Vol. 25, No. 2, pp. 151-62.

Alpanda, S., \& Honig, A. (2009). The Impact of Central Bank Independence on Political Monetary Cycles in Advanced and Developing Nations. Journal of Money, Credit and Banking, Vol. 41, pp. 1365-1389.

Arellano, M., \& Bover, O. (1995). Another look at the instrumental variable estimation of error-components models. Journal of Econometrics, Vol. 68(1), pp. 29-51.

Blanchard, O. (2004). Fiscal Dominance and Inflation Targeting: Lessons from Brazil. National Bureau of Economic Research, NBER Working Papers 10389.

Blundell, R., \& Bond, S. (1998). Initial conditions and moment restrictions in dynamic panel data models. Journal of Econometrics, Vol. 87, pp. 115-43.

Bordo, M. D., \& Siklos, P. L. (2018). Central Banks: Evolution and Innovation in Historical Perspective. En R. Edvinsson, T. Jacobson, \& D. Waldenström, Sveriges Riksbank and the History of Central Banking (págs. 26-89). Cambridge: Cambridge University Press.

Cagan, P. (1956). The monetary dynamics of hyperinflation. En M. Friedman, Studies in the Quantity Theory of Money (págs. 355-362). Chicago: University of Chicago Press.

Cottarelli, C. (1993). Limiting Central Bank Credit to the Government, Theory and Practice. IMF Occasional Paper, No. 110.

Cotterill, J. (9 de August de 2020). South Africa's central bank defends pandemic response. Financial Times.

Fischer, S. (1995). Central-Bank Independence Revisited. American Economic Review, Vol. 85, No. 2, pp. 201-06.

Garriga, A. C., \& Rodriguez, C. M. (2020). More Effective than We Thought: Central Bank Independence and Inflation in Developing Countries. Economic Modeling, Vol. 85, No.1, pp. 87-105.

Hanke, S. H., \& Krus, N. (2012). World Hyperinflations. En R. Parker, \& R. Whaples, The Handbook of Major Events in Economic History. London: Routledge Publishing.

International Monetary Fund. (2014). Sub-Saharan Africa: Regional Economic Outlook, April. Washington: International Monetary Fund.

International Monetary Fund. (2018). Sub-Saharan Africa: Regional Economic Outlook, October. Washington: International Monetary Fund.

International Monetary Fund. (2020). Sub-Saharan Africa: Regional Economic Outlook, April. Washington: International Monetary Fund.

Jácome, L. I., Matamoros-Indorf, M., Sharma, M., \& Townsend, S. (2012). Central Bank Credit to the Government: What Can We Learn from International Practices? IMF Working Paper, 12/16.

Jordà, Ò. (2005). Estimation and Inference of Impulse Responses by Local Projections. American Economic Review, Vol. 95, No. 1, pp. 161-182.

Ministry of Finance of Ghana. (30 de May de 2020). News and Events. Obtenido de Bank of Ghana Asset Purchase Programme as part of Covid-19 Relief Bond Programme: https://www.mofep.gov.gh 
Nachega, J.-C. (2005). Fiscal Dominance and Inflation in the Democratic Republic of the Congo. IMF Working Paper, 05/221.

Sikken, B. J., \& De Haan, J. (1998). Budget Deficits, Monetization, and CB Autonomy in Developing Countries. Oxford Economic Papers, Vol. 50, pp. 493-511.

Sims, C. A. (1980). Macroeconomics and Reality. Econometrica, Vol. 48, No. 1, pp. 1-48. 


\section{ANNEX I}

Table A1. Sub-Saharan Africa: Central Bank Acts, 2017

\begin{tabular}{|c|c|c|c|}
\hline Country name & Legal limit & Name of most recent legislation & $\begin{array}{c}\text { Year current } \\
\text { legislation took effect } \\
\text { (last amendment) }\end{array}$ \\
\hline Angola & $\begin{array}{l}10 \% \text { of previous year's } \\
\text { revenue }\end{array}$ & $\begin{array}{l}\text { Banco Nacional de Angola Act. Law } \\
\text { No. } 16 / 1015 \text { July }\end{array}$ & 2010 \\
\hline Benin & $0 \%$ & $\begin{array}{l}\text { Treaty of the West African Monetary } \\
\text { Union (UEMOA) }\end{array}$ & $\mathrm{N} / \mathrm{S}$ \\
\hline Botswana & $\begin{array}{l}5 \% \text { of previous three } \\
\text { years' average revenue }\end{array}$ & The Bank of Botswana Act. 1996 & 1997 \\
\hline Burkina Faso & $0 \%$ & $\begin{array}{l}\text { Treaty of the West African Monetary } \\
\text { Union (UEMOA) }\end{array}$ & $\mathrm{N} / \mathrm{S}$ \\
\hline Burundi & N/A & & \\
\hline Cabo Verde & $\begin{array}{l}5 \% \text { of previous year's } \\
\text { revenue }\end{array}$ & $\begin{array}{l}\text { Organic Law of the Bank of Cape } \\
\text { Verde, } 2002\end{array}$ & 2002 \\
\hline Cameroon & $\begin{array}{l}20 \% \text { of previous year's } \\
\text { revenue }\end{array}$ & $\begin{array}{l}\text { Charter of the Bank of Central } \\
\text { African States, } 2010 \text { (CEMAC) }\end{array}$ & 2010 \\
\hline $\begin{array}{l}\text { Central African } \\
\text { Republic }\end{array}$ & $\begin{array}{l}20 \% \text { of previous year's } \\
\text { revenue }\end{array}$ & $\begin{array}{l}\text { Charter of the Bank of Central } \\
\text { African States, } 2010 \text { (CEMAC) }\end{array}$ & 2010 \\
\hline Chad & $\begin{array}{l}20 \% \text { of previous year's } \\
\text { revenue }\end{array}$ & $\begin{array}{l}\text { Charter of the Bank of Central } \\
\text { African States, } 2010 \text { (CEMAC) }\end{array}$ & 2010 \\
\hline Comoros & $\begin{array}{l}20 \% \text { of previous three } \\
\text { years' average revenue }\end{array}$ & $\begin{array}{l}\text { Statuts de la Banque Centrale des } \\
\text { Comoros, } 2008\end{array}$ & 2008 \\
\hline $\begin{array}{l}\text { Congo, Democratic } \\
\text { Rep. of }\end{array}$ & $0 \%$ & $\begin{array}{l}\text { Law } 005 / 2002 \text { on the Establishment, } \\
\text { Organization, and Operations of the } \\
\text { Central Bank of Congo, May 7, } 2002\end{array}$ & 2002 \\
\hline Congo, Republic of & $\begin{array}{l}20 \% \text { of previous year's } \\
\text { revenue }\end{array}$ & $\begin{array}{l}\text { Charter of the Bank of Central } \\
\text { African States, } 2010 \text { (CEMAC) }\end{array}$ & 2010 \\
\hline Côte d'Ivoire & $0 \%$ & $\begin{array}{l}\text { Treaty of the West African Monetary } \\
\text { Union (UEMOA) }\end{array}$ & $\mathrm{N} / \mathrm{S}$ \\
\hline Equatorial Guinea & $\begin{array}{l}20 \% \text { of previous year's } \\
\text { revenue }\end{array}$ & $\begin{array}{l}\text { Charter of the Bank of Central } \\
\text { African States, } 2010 \text { (CEMAC) }\end{array}$ & 2010 \\
\hline Eritrea & N/A & & \\
\hline Ethiopia & $\mathrm{N} / \mathrm{S}$ & $\begin{array}{l}\text { Monetary and Banking Proclamation } \\
\text { No. } 183 / 1994 \text { and No. 591/2008 }\end{array}$ & $1994(2008)$ \\
\hline Gabon & $\begin{array}{l}20 \% \text { of previous year's } \\
\text { revenue }\end{array}$ & $\begin{array}{l}\text { Charter of the Bank of Central } \\
\text { African States, } 2010 \text { (CEMAC) }\end{array}$ & 2010 \\
\hline Gambia, The & $\begin{array}{l}10 \% \text { of previous year's } \\
\text { revenue }\end{array}$ & Central Bank of Gambia Act, 2005 & 2005 \\
\hline Ghana & $\begin{array}{l}5 \% \text { of current year's } \\
\text { revenue }\end{array}$ & $\begin{array}{l}\text { Bank of Ghana Act, 24th January } \\
2002\end{array}$ & $2002(2016)$ \\
\hline Guinea & $\begin{array}{l}5 \% \text { of previous year's } \\
\text { revenue }\end{array}$ & $\begin{array}{l}\text { Charter of the Central Bank of the } \\
\text { Republic of Guinea, } 1994\end{array}$ & $1994(2017)$ \\
\hline
\end{tabular}


Table A1. Sub-Saharan Africa: Central Bank Act, 2017 (Continued)

\begin{tabular}{|c|c|c|c|}
\hline Country name & Legal limit & Name of most recent legislation & $\begin{array}{c}\text { Year current } \\
\text { legislation took effect } \\
\text { (last amendment) }\end{array}$ \\
\hline Guinea-Bissau & $0 \%$ & $\begin{array}{l}\text { Treaty of the West African Monetary } \\
\text { Union (UEMOA) }\end{array}$ & $\mathrm{N} / \mathrm{S}$ \\
\hline Kenya & $\begin{array}{l}5 \% \text { of previous year's } \\
\text { revenue }\end{array}$ & The Central Bank of Kenya Act & 1966 (2014) \\
\hline Lesotho & $\begin{array}{l}\text { Net claim is } 5 \% \text { of } \\
\text { previous year's budget }\end{array}$ & Central Bank of Lesotho Act, 2000 & 2000 \\
\hline Madagascar & $\begin{array}{l}7 \% \text { of previous year's } \\
\text { revenue }\end{array}$ & $\begin{array}{l}\text { Charter of the Central Bank of } \\
\text { Madagascar, } 1994\end{array}$ & $1994(2016)$ \\
\hline Malawi & $\begin{array}{l}20 \% \text { of current year's } \\
\text { revenue }\end{array}$ & $\begin{array}{l}\text { Reserve Bank of Malawi Act - Laws of } \\
\text { Malawi (Chapter 44:02), } 1989\end{array}$ & 1989 \\
\hline Mali & $0 \%$ & $\begin{array}{l}\text { Treaty of the West African Monetary } \\
\text { Union (UEMOA) }\end{array}$ & $\mathrm{N} / \mathrm{S}$ \\
\hline Mauritania & $\begin{array}{l}5 \% \text { of previous year's } \\
\text { revenue }\end{array}$ & $\begin{array}{l}\text { Charter of the Central Bank of } \\
\text { Mauritania }\end{array}$ & 2007 \\
\hline Mauritius & $\begin{array}{l}10 \% \text { of current year's } \\
\text { revenue }\end{array}$ & The Bank of Mauritius Act, 2004 & $2004(2015)$ \\
\hline Mozambique & $\begin{array}{l}10 \% \text { of previous year's } \\
\text { revenue }\end{array}$ & Law 1/92 of January 3, 1992 & 1992 \\
\hline Namibia & $\begin{array}{l}25 \% \text { of previous three } \\
\text { years' average revenue }\end{array}$ & Bank of Namibia Act, 1997 & 1997 \\
\hline Niger & $0 \%$ & $\begin{array}{l}\text { Treaty of the West African Monetary } \\
\text { Union (UEMOA) }\end{array}$ & $\mathrm{N} / \mathrm{S}$ \\
\hline Nigeria & $\begin{array}{l}5 \% \text { of previous year's } \\
\text { revenue }\end{array}$ & Central Bank of Nigeria Act, 2007 & 2007 \\
\hline Rwanda & $\begin{array}{l}11 \% \text { of previous year's } \\
\text { government revenue }\end{array}$ & $\begin{array}{l}\text { Law No. 55/2007 of 30/11/2007 } \\
\text { Governing the Central Bank of } \\
\text { Rwanda }\end{array}$ & 2007 \\
\hline $\begin{array}{l}\text { São Tomé and } \\
\text { Príncipe }\end{array}$ & $\begin{array}{l}5 \% \text { of previous year's } \\
\text { revenue }\end{array}$ & $\begin{array}{l}\text { Law 8/92, Organic Law of the Central } \\
\text { Bank of STP, } 1992\end{array}$ & 1992 \\
\hline Senegal & $0 \%$ & $\begin{array}{l}\text { Treaty of the West African Monetary } \\
\text { Union (UEMOA) }\end{array}$ & $\mathrm{N} / \mathrm{S}$ \\
\hline Seychelles & $\mathrm{N} / \mathrm{S}$ & Central Bank of Seychelles Act, 2004 & $2004(2011)$ \\
\hline Sierra Leone & $\begin{array}{l}5 \% \text { of previous year's } \\
\text { revenue }\end{array}$ & Bank of Sierra Leone Act, 2000 & 2000 \\
\hline South Africa & $\mathrm{N} / \mathrm{S}$ & $\begin{array}{l}\text { South African Reserve Bank Act 90, } \\
1989\end{array}$ & 1989 \\
\hline Sudan & $\begin{array}{l}15 \% \text { of current year's } \\
\text { revenue }\end{array}$ & The Bank of Sudan Act, 2002 & 2002 \\
\hline Swaziland (Eswatini) & $\begin{array}{l}20 \% \text { of previous three } \\
\text { years' average revenue }\end{array}$ & $\begin{array}{l}\text { The Central Bank of Swaziland Order, } \\
1974\end{array}$ & 1974 (1979) \\
\hline Tanzania & $\begin{array}{l}12.5 \% \text { of previous year's } \\
\text { revenue }\end{array}$ & The Bank of Tanzania Act, 2006 & $2006(2010)$ \\
\hline
\end{tabular}




\begin{tabular}{|c|c|c|c|}
\hline Togo & $0 \%$ & $\begin{array}{l}\text { Treaty of the West African Monetary } \\
\text { Union (UEMOA) }\end{array}$ & $\mathrm{N} / \mathrm{S}$ \\
\hline Uganda & $\begin{array}{l}18 \% \text { of previous year's } \\
\text { revenue }\end{array}$ & The Bank of Uganda Statute, 1993 & $1993(2010)$ \\
\hline Zambia & $\begin{array}{l}15 \% \text { of previous year's } \\
\text { revenue }\end{array}$ & $\begin{array}{l}\text { Bank of Zambia (Amendment) Act, } \\
1998\end{array}$ & 1998 \\
\hline Zimbabwe & $\begin{array}{l}20 \% \text { of previous year's } \\
\text { revenue }\end{array}$ & $\begin{array}{l}\text { Reserve Bank of Zimbabwe Act } \\
\text { (Chapter 22:15) }\end{array}$ & 2010 \\
\hline
\end{tabular}

Sources: National Authorities; and Central Bank Legislation Database (CBLD).

Notes: N/S indicates not specified in the Central Bank Act, while N/A indicates no Central Bank Act was found in the CBLD database or on the websites of the relevant Central Bank or Ministry of Finance.

\section{ANNEX II}

This annex presents the results of the robustness tests conducted and described in section III.

1. Treating the fiscal deficit as endogenous. Use lagged values of all independent variables.

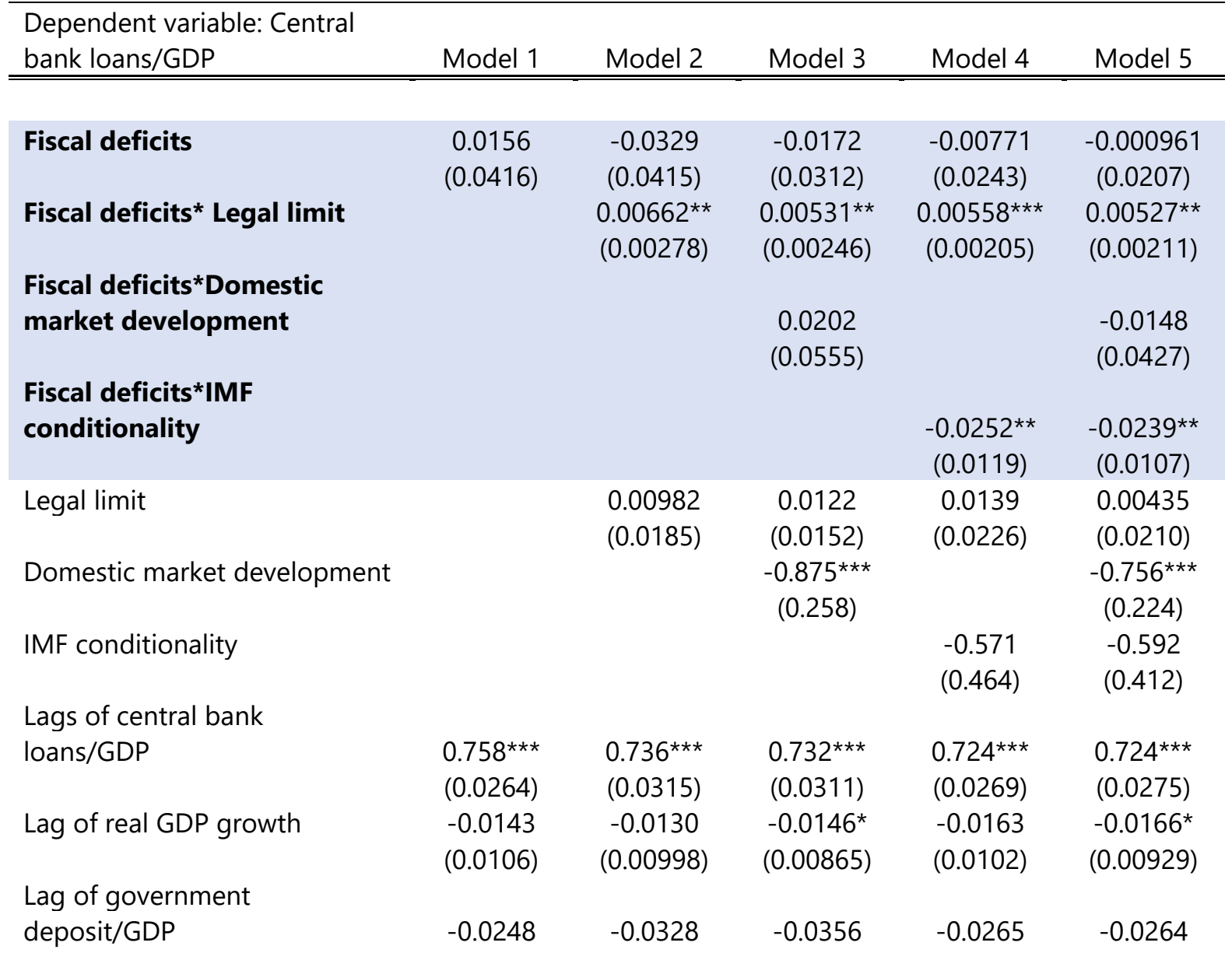




\begin{tabular}{lccccc} 
& $(0.0443)$ & $(0.0341)$ & $(0.0314)$ & $(0.0270)$ & $(0.0270)$ \\
Lag of government debt/GDP & -0.00220 & $0.00573^{* *}$ & $0.00586^{* *}$ & $0.00512^{* *}$ & $0.00421^{* *}$ \\
& $(0.00380)$ & $(0.00248)$ & $(0.00243)$ & $(0.00227)$ & $(0.00203)$ \\
Observations & 667 & 596 & 596 & 596 & 596 \\
Number of countries & 45 & 41 & 41 & 41 & 41 \\
\hline
\end{tabular}

Robust standard errors in parentheses

*** $p<0.01,{ }^{* *} p<0.05,{ }^{*} p<0.1$

2. Total claims. The stock of outstanding loans is used in our baseline model as it corresponds to the definition of the legal limit in central bank Acts. But some countries may interpret the law flexibly and ask the central bank to lend through other channels. In such cases, total claims would be a better measure of fiscal dominance.

\begin{tabular}{|c|c|c|c|c|c|}
\hline $\begin{array}{l}\text { Dependent variable: Central } \\
\text { bank claims/GDP }\end{array}$ & Model 1 & Model 2 & Model 3 & Model 4 & Model 5 \\
\hline Fiscal deficits & $\begin{array}{l}0.145^{\star \star \star} \\
(0.0460)\end{array}$ & $\begin{array}{l}0.0375^{*} \\
(0.0228)\end{array}$ & $\begin{array}{l}0.0398^{*} \\
(0.0210)\end{array}$ & $\begin{array}{c}0.0274 \\
(0.0245)\end{array}$ & $\begin{array}{c}0.0298 \\
(0.0230)\end{array}$ \\
\hline Fiscal deficits* Legal limit & & $\begin{array}{l}0.00368^{* *} \\
(0.00152)\end{array}$ & $\begin{array}{l}0.00382^{* *} \\
(0.00162)\end{array}$ & $\begin{array}{l}0.00440^{* *} \\
(0.00199)\end{array}$ & $\begin{array}{l}0.00460^{* *} \\
(0.00203)\end{array}$ \\
\hline $\begin{array}{l}\text { Fiscal deficits*Domestic } \\
\text { market development }\end{array}$ & & & $\begin{array}{l}-0.0184 \\
(0.0373)\end{array}$ & & $\begin{array}{l}-0.0187 \\
(0.0355)\end{array}$ \\
\hline $\begin{array}{l}\text { Fiscal deficits*IMF } \\
\text { conditionality }\end{array}$ & & & & $\begin{array}{l}-0.0183 \\
(0.0153)\end{array}$ & $\begin{array}{l}-0.0181 \\
(0.0135)\end{array}$ \\
\hline $\begin{array}{l}\text { Legal limit (measured in percent } \\
\text { of revenue) }\end{array}$ & & $\begin{array}{c}0.0339 \\
(0.0382)\end{array}$ & $\begin{array}{c}0.0384 \\
(0.0390)\end{array}$ & $\begin{array}{c}0.0320 \\
(0.0404)\end{array}$ & $\begin{array}{c}0.0359 \\
(0.0410)\end{array}$ \\
\hline Domestic market development & & & $\begin{array}{l}-0.672 \\
(0.466)\end{array}$ & & $\begin{array}{l}-0.589 \\
(0.459)\end{array}$ \\
\hline IMF conditionality & & & & $\begin{array}{l}-0.619 \\
(0.640)\end{array}$ & $\begin{array}{l}-0.531 \\
(0.615)\end{array}$ \\
\hline Lags of central bank claims/GDP & $\begin{array}{l}0.897^{\star \star \star} \\
(0.0752)\end{array}$ & $\begin{array}{l}0.827^{* * *} \\
(0.0360)\end{array}$ & $\begin{array}{l}0.827^{\star \star \star} \\
(0.0374)\end{array}$ & $\begin{array}{l}0.824^{* * *} \\
(0.0335)\end{array}$ & $\begin{array}{l}0.825^{* * *} \\
(0.0348)\end{array}$ \\
\hline Lag of real GDP growth & $\begin{array}{l}-0.0270 \\
(0.0174)\end{array}$ & $\begin{array}{l}-0.0254 \\
(0.0206)\end{array}$ & $\begin{array}{l}-0.0235 \\
(0.0192)\end{array}$ & $\begin{array}{l}-0.0270 \\
(0.0211)\end{array}$ & $\begin{array}{l}-0.0252 \\
(0.0195)\end{array}$ \\
\hline Lag of government deposit/GDP & $\begin{array}{l}-0.0839 \\
(0.0768)\end{array}$ & $\begin{array}{l}-0.0733 \\
(0.0626)\end{array}$ & $\begin{array}{l}-0.0786 \\
(0.0634)\end{array}$ & $\begin{array}{l}-0.0704 \\
(0.0643)\end{array}$ & $\begin{array}{l}-0.0756 \\
(0.0652)\end{array}$ \\
\hline Lag of government debt/GDP & $\begin{array}{l}-0.0148 * \star \\
(0.00676)\end{array}$ & $\begin{array}{l}-0.0105 \\
(0.00779)\end{array}$ & $\begin{array}{l}-0.0103 \\
(0.00797)\end{array}$ & $\begin{array}{l}-0.0129 * \\
(0.00772)\end{array}$ & $\begin{array}{l}-0.0125 \\
(0.00776)\end{array}$ \\
\hline Observations & 667 & 596 & 596 & 596 & 596 \\
\hline Number of countries & 45 & 41 & 41 & 41 & 41 \\
\hline
\end{tabular}

Robust standard errors in parentheses 
*** $p<0.01,{ }^{* *} p<0.05,{ }^{*} p<0.1$

3. Changes. We use stock of loans in our baseline specification as it corresponds to the definition of the legal limit in central bank Acts. But some countries may interpret the law differently. Flow also more closely corresponds to annual financing needs.

\begin{tabular}{|c|c|c|c|c|c|}
\hline $\begin{array}{l}\text { Dependent variable: Change in } \\
\text { Central bank loans/GDP }\end{array}$ & Model 1 & Model 2 & Model 3 & Model 4 & Model 5 \\
\hline Fiscal deficits & $\begin{array}{l}0.626^{\star \star} \\
(0.304)\end{array}$ & $\begin{array}{l}0.0935 \\
(0.237)\end{array}$ & $\begin{array}{c}0.102 \\
(0.237)\end{array}$ & $\begin{array}{l}-0.0331 \\
(0.252)\end{array}$ & $\begin{array}{l}-0.0253 \\
(0.254) \\
0.0565^{* *}\end{array}$ \\
\hline Fiscal deficits* Legal limit & & $\begin{array}{c}0.0415^{\star * \star} \\
(0.0159)\end{array}$ & $\begin{array}{c}0.0441^{* * *} \\
(0.0157)\end{array}$ & $\begin{array}{c}0.0540^{* * *} \\
(0.0205)\end{array}$ & $\begin{array}{c}* \\
(0.0200)\end{array}$ \\
\hline $\begin{array}{l}\text { Fiscal deficits*Domestic market } \\
\text { development }\end{array}$ & & & $\begin{array}{l}-0.182 \\
(0.350)\end{array}$ & & $\begin{array}{l}-0.193 \\
(0.332)\end{array}$ \\
\hline Fiscal deficits*IMF conditionality & & & & $\begin{array}{l}-0.243^{*} \\
(0.126)\end{array}$ & $\begin{array}{c}-0.237^{* *} \\
(0.115)\end{array}$ \\
\hline Legal limit & & $\begin{array}{c}0.676 \\
(0.563)\end{array}$ & $\begin{array}{l}0.613 \\
(0.501)\end{array}$ & $\begin{array}{c}0.559 \\
(0.496)\end{array}$ & $\begin{array}{c}0.477 \\
(0.442)\end{array}$ \\
\hline Domestic market development & & & $\begin{array}{l}3.946 \\
(5.673)\end{array}$ & & $\begin{array}{c}4.912 \\
(4.964)\end{array}$ \\
\hline IMF conditionality & & & & $\begin{array}{l}-8.823 \\
(6.865)\end{array}$ & $\begin{array}{l}-9.282 \\
(6.963)\end{array}$ \\
\hline $\begin{array}{l}\text { Lags of change in central bank } \\
\text { loans/GDP }\end{array}$ & $\begin{array}{l}-0.195^{\star *} \\
(0.0942)\end{array}$ & $\begin{array}{c}0.0203 \\
(0.0628)\end{array}$ & $\begin{array}{c}0.0146 \\
(0.0677)\end{array}$ & $\begin{array}{l}0.00520 \\
(0.0632)\end{array}$ & $\begin{array}{r}-0.00215 \\
(0.0689)\end{array}$ \\
\hline Lag of real GDP growth & $\begin{array}{l}-0.187 \\
(0.164)\end{array}$ & $\begin{array}{l}-0.206 \\
(0.208)\end{array}$ & $\begin{array}{l}-0.196 \\
(0.215)\end{array}$ & $\begin{array}{l}-0.213 \\
(0.221)\end{array}$ & $\begin{array}{l}-0.200 \\
(0.227)\end{array}$ \\
\hline Lag of government deposit/GDP & $\begin{array}{l}-1.134^{*} \\
(0.619)\end{array}$ & $\begin{array}{l}-0.814^{*} \\
(0.475)\end{array}$ & $\begin{array}{l}-0.771^{*} \\
(0.456)\end{array}$ & $\begin{array}{l}-0.739 \\
(0.470)\end{array}$ & $\begin{array}{l}-0.689 \\
(0.449)\end{array}$ \\
\hline Lag of government debt/GDP & $\begin{array}{l}-0.0873^{*} \\
(0.0468)\end{array}$ & $\begin{array}{l}-0.0132 \\
(0.0818)\end{array}$ & $\begin{array}{l}-0.00591 \\
(0.0852)\end{array}$ & $\begin{array}{l}-0.0373 \\
(0.0753)\end{array}$ & $\begin{array}{l}-0.0280 \\
(0.0771)\end{array}$ \\
\hline Observations & 629 & 561 & 561 & 561 & 561 \\
\hline Number of countries & 45 & 41 & 41 & 41 & 41 \\
\hline
\end{tabular}

Robust standard errors in parentheses

*** $p<0.01,{ }^{* *} p<0.05,{ }^{*} p<0.1$

4. Additional explanatory variables. We test whether alternative aspects of outside financing conditions play a role: risk and external financing.

\begin{tabular}{lccc}
\hline Dependent variable: Central bank loans/GDP & Model 1 & Model 2 & Model 3 \\
\hline \hline & & & \\
Fiscal deficits & 0.0370 & $0.0734^{\star}$ & $0.0752^{*}$ \\
& $(0.0253)$ & $(0.0394)$ & $(0.0400)$
\end{tabular}




\begin{tabular}{|c|c|c|c|}
\hline Fiscal deficits* Legal limit & $\begin{array}{c}0.00458^{\star * *} \\
(0.00154)\end{array}$ & $\begin{array}{l}0.00562^{\star *} \\
(0.00218)\end{array}$ & $\begin{array}{l}0.00557^{* *} \\
(0.00217)\end{array}$ \\
\hline $\begin{array}{l}\text { Fiscal deficits*Domestic market dvpt+Eurobond } \\
\text { access }\end{array}$ & $\begin{array}{l}-0.0358 \\
(0.0778)\end{array}$ & & $\begin{array}{c}-0.0887 \\
(0.113)\end{array}$ \\
\hline Fiscal deficits*Sovereign risk & & $\begin{array}{l}-0.00537 \\
(0.00420)\end{array}$ & $\begin{array}{l}-0.00536 \\
(0.00418)\end{array}$ \\
\hline Legal limit & $\begin{array}{l}-0.00132 \\
(0.0321)\end{array}$ & $\begin{array}{l}-0.0181 \\
(0.0470)\end{array}$ & $\begin{array}{l}-0.0172 \\
(0.0474)\end{array}$ \\
\hline Domestic market dvpt+ Eurobond access & $\begin{array}{c}0.174 \\
(0.640)\end{array}$ & & $\begin{array}{c}0.670 \\
(0.891)\end{array}$ \\
\hline Sovereign risk & & $\begin{array}{c}-0.0541 \\
(0.156)\end{array}$ & $\begin{array}{c}-0.0576 \\
(0.151)\end{array}$ \\
\hline Lags of central bank loans/GDP & $\begin{array}{l}0.795^{* * *} \\
(0.0382)\end{array}$ & $\begin{array}{l}0.791^{* * *} \\
(0.0533)\end{array}$ & $\begin{array}{l}0.789 * * * \\
(0.0533)\end{array}$ \\
\hline Lag of real GDP growth & $\begin{array}{c}-0.0221^{* *} \\
(0.0108)\end{array}$ & $\begin{array}{l}-0.0207 \\
(0.0145)\end{array}$ & $\begin{array}{l}-0.0204 \\
(0.0147)\end{array}$ \\
\hline Lag of government deposit/GDP & $\begin{array}{l}-0.0805 \\
(0.0605)\end{array}$ & $\begin{array}{c}-0.127 \\
(0.0888)\end{array}$ & $\begin{array}{c}-0.124 \\
(0.0885)\end{array}$ \\
\hline Lag of government debt/GDP & $\begin{array}{l}-0.00343 \\
(0.00659)\end{array}$ & $\begin{array}{l}-0.00226 \\
(0.00677)\end{array}$ & $\begin{array}{l}-0.00225 \\
(0.00663)\end{array}$ \\
\hline Observations & 596 & 443 & 443 \\
\hline Number of countries & 41 & 35 & 35 \\
\hline
\end{tabular}

Robust standard errors in parentheses

*** $p<0.01,{ }^{* *} p<0.05, * p<0.1$

Notes: Sovereign risk measures the risk of debt distress using the ratings from the IMF's Debt Sustainability Analysis ( $=0$ if rating is "Low"; $=1$ if rating is "Moderate" $=2$ if rating is "High" $=3$ if rating is "In debt distress"). Eurobond access is a dummy (=1 if the country has previously issued a Eurobond, 0 otherwise). 


\section{ANNEX III}

This table provides information on the sample used for estimating the IRFs using the Local Projection method described in Section IV.

Table A2: Number of Observations (Countries) in each Local Projection

\begin{tabular}{lccccccc}
\hline \multirow{2}{*}{ Dependent variable } & \multicolumn{7}{c}{ Horizon } \\
\cline { 2 - 7 } & 0 & 1 & 2 & 3 & 4 & 5 & 6 \\
\hline Base Money & 580 & 545 & 507 & 469 & 430 & 391 & 354 \\
& $(40)$ & $(40)$ & $(40)$ & $(40)$ & $(40)$ & $(38)$ & $(37)$ \\
\hline Exchange Rate & 596 & 560 & 521 & 482 & 442 & 402 & 364 \\
& $(41)$ & $(41)$ & $(41)$ & $(41)$ & $(41)$ & $(39)$ & $(38)$ \\
\hline Inflation & 596 & 560 & 521 & 482 & 442 & 402 & 364 \\
& $(41)$ & $(41)$ & $(41)$ & $(41)$ & $(41)$ & $(39)$ & $(38)$ \\
Broad Money & 596 & 560 & 521 & 482 & 442 & 402 & 364 \\
& $(41)$ & $(41)$ & $(41)$ & $(41)$ & $(41)$ & $(39)$ & $(38)$ \\
\hline
\end{tabular}

Note: The Table summarizes the number of observations and the number of countries in each Local Projection. The number of observations in each regression are less than in the summary statistics because a full set of data is not available for all the control variables. 


\section{ANNEX III}

This annex presents the list of the 45 Sub-Saharan countries used in the analysis of this paper.

\begin{tabular}{|c|c|}
\hline Angola & Madagascar \\
\hline Benin & Malawi \\
\hline Botswana & Mali \\
\hline Burkina Faso & Mauritania \\
\hline Burundi & Mauritius \\
\hline Cabo Verde & Mozambique \\
\hline Cameroon & Namibia \\
\hline Central African Republic & Niger \\
\hline Chad & Nigeria \\
\hline Comoros & Rwanda \\
\hline Congo, Democratic Republic of the & São Tomé and Principe \\
\hline Congo, Rep. & Senegal \\
\hline Côte d'Ivoire & Seychelles \\
\hline Equatorial Guinea & Sierra Leone \\
\hline Eritrea & South Africa \\
\hline Ethiopia & Sudan \\
\hline Gabon & Swaziland \\
\hline Gambia, The & Tanzania \\
\hline Ghana & Togo \\
\hline Guinea & Uganda \\
\hline Guinea-Bissau & Zambia \\
\hline Kenya & Zimbabwe \\
\hline Lesotho & \\
\hline
\end{tabular}

